\title{
MUTATION OF ASPERGILLUS ORYZAE FOR IMPROVED PRODUCTION OF 3, 4-DIHYDROXY PHENYL-L-ALANINE (L-DOPA) FROM L-TYROSINE
}

\author{
Ikram-ul-Haq*; Sikander Ali \\ Biotechnology Research Centre, Department of Botany, Government College University Lahore, Pakistan \\ Submitted: November 22, 2004; Returned to authors for corrections: March 21, 2005; Approved: January 30, 2006
}

\begin{abstract}
Aspergillus oryzae mutant strain UV-7 was further improved for the production of L-DOPA from L-tyrosine using chemical mutation. Different putative mutant strains of organism were tested for the production of LDOPA in submerged fermentation. Among these putative mutant strains, mutant designated SI-12 gave maximum production of L-DOPA (300 mg L-DOPA. $\mathrm{g}^{-1}$ cells). The production of L-DOPA from different carbon source solutions $\left(\mathrm{S}_{0}=30 \mathrm{~g} . \mathrm{l}^{-1}\right)$ by mutant culture was investigated at different nitrogen sources, initial $\mathrm{pH}$ and temperature values. At optimum $\mathrm{pH}\left(\mathrm{pH}_{0}=5.0\right)$, and temperature $\left(\mathrm{t}=30^{\circ} \mathrm{C}\right), 100 \%$ sugars were utilized for production and cell mass formation, corresponding to final L-DOPA product yield of $150 \mathrm{mg} \cdot \mathrm{g}^{-1}$ substrate utilized, and maximum volumetric and specific productivities of $125 \mathrm{mg} \cdot \mathrm{l}^{-1} \cdot \mathrm{h}^{-1}$, and $150 \mathrm{mg} \cdot \mathrm{g}^{-1}$ cells. $\mathrm{h}^{-1}$, respectively. There was up to 3 -fold enhancement in product formation rate. This enhancement is the highest reported in literature. To explain the kinetic mechanism of L-DOPA formation and thermal inactivation of tyrosinase, the thermodynamic parameters were determined with the application of Arrhenius model: activation enthalpy and entropy for product formation, in case of mutant derivative, were $40 \mathrm{k} \mathrm{j} / \mathrm{mol}$ and $0.076 \mathrm{k} \mathrm{j} / \mathrm{mol}$. K for L-DOPA production and $116 \mathrm{k} \mathrm{j} / \mathrm{mol}$ and $0.590 \mathrm{k} \mathrm{j} / \mathrm{mol}$. $\mathrm{K}$ for thermal inactivation, respectively. The respective values for product formation were lower while those for product deactivation were higher than the respective values for the parental culture. Therefore, the mutant strain was thermodynamically more resistant to thermal denaturation.
\end{abstract}

Key words: Aspergillus oryzae, L-DOPA, thermodynamic parameters

\section{INTRODUCTION}

L-DOPA (3, 4-dihydroxyphenyl L-alanine) is an amino acid analogue, isolated from various plant sources but not found in the animal body. It is a very useful drug in the treatment of Parkinson's disease, a degenerative disorder that causes rigidity, tremors, slowness of speech and eventually dementia, and for controlling the changes in enzymes of energy metabolism of myocardium following neurogenic injury $(15,16)$. This disorder is associated with diminished level of dopamine in brain and is commonly treated by oral administration of L-DOPA, which is a precursor of dopamine as the former can transverse the bloodbrain barrier while the latter cannot move across the blood- brain barrier. The success of L-DOPA stimulated the neurochemistry research for all neurodegenrative diseases. The chemical synthesis of L-DOPA involves use of several chemicals and catalysts under harsh production conditions $(15,16)$. Alternate procedures are; its extraction from biological sources where it exists abundantly and production by intact microbes. These methods may provide enhanced product formation rate economically under mild process conditions.

L-DOPA occurs naturally in seedlings, pods and beans of Vicia faba and in the seeds of Mucana pruriens. Sih et al. (25) first reported the production of L-DOPA from L-tyrosine by fungi. Haneda et al. (10) used Aspergillus oryzae for the conversion of L-tyrosine to L-DOPA. L-DOPA is produced from

*Corresponding Author. Mailing address: Biotechnology Research Centre, Department of Botany, Government College University Lahore, Pakistan. E-mail: ikrhaq@yahoo.com 
L-tyrosine by the one step oxidation reaction catalyzed by the enzyme tyrosinase, tyrosine hydroxylase or $\beta$-tyrosinase in living organisms $(11,23)$. Tyrosinases (EC 1.14.1.18.1) are widely distributed in nature and have been purified to homogeneity level. They are derived from microbial and plant sources (13). Tyrosinases are also known to exist in several fungi such as Neurospora crassa and Agricus bispora, and they have been used for the production of L-DOPA from L-tyrosine (17). However, in microorganisms tyrosinase activity is generally very weak and L-tyrosine and L-DOPA are rapidly decomposed to other metabolites. Thus stoichiometric formation of L-DOPA from L-tyrosine is difficult to achieve (25).

The present work was undertaken to develop Aspergillus oryzae mutant strain for the production of L-DOPA from Ltyrosine following chemical mutagenesis. The tyrosinase was located intracellularly. Mould mycelium, after harvesting from the fermented broth, was used for biochemical transformation of L-tyrosine to L-DOPA under reduced conditions. Final mutant was 3-fold improved over its wild strain with respect to all product formation parameters. The yield profiles were significantly $(\mathrm{P} \leq 0.05)$ higher than those calculated form the results of some other workers. The mutant strain and tyrosinase elaborated by it were thermodynamically more resistant to thermal inactivation.

\section{MATERIALS AND METHODS}

\section{Microorganism}

Aspergillus oryzae (parental culture) and mutant strain UV7, collected from Government College University Culture Collection (GCU Lahore - Pakistan), were used in the present studies.

\section{Cultivation medium}

Submerged culture method (22) was employed for cultivation of mycelium in Vogel's medium containing $(\mathrm{g} / \mathrm{L})$ glucose 20 , trisodium citrate 2.5, $\mathrm{NH}_{4} \mathrm{NO}_{3} 2.0, \mathrm{KH}_{2} \mathrm{PO}_{4} 5.0,\left(\mathrm{NH}_{4}\right)_{2} \mathrm{SO}_{4} 4.0$, $\mathrm{MgSO}_{4} .7 \mathrm{H}_{2} \mathrm{O} 0.2$, yeast extract $1.0(\mathrm{pH} 5.0)$

\section{Induction of mutation}

The strain of Aspergillus oryzae UV-7 was improved by chemical mutagenesis. The fungal inoculum was prepared in Vogel's medium, centrifuged aseptically at $5000 \mathrm{rpm}$ for $10 \mathrm{~min}$, washed in sterilized saline water, recentrifuged and suspended in $50 \mathrm{~mL}$ sterilized saline water in tubes. Different amounts (250-1500 $\mu \mathrm{g}$ ) of 1-methyl 3-nitro 1-nitroso guanidine (NTG) were transferred to different tubes for different time intervals (0-30 min). After the time interval of $15 \mathrm{~min}$, which gave $3 \mathrm{log}$ kill $(8,20)$, cells were washed to get them free of NTG and allowed to get them expressed to a cell absorbance of 0.9 .

A serial dilution was applied to the expressed cells and plated on malt extract-agar plates to get approximately 30 colonies per plate $(8,20)$. Overall, 60 different larger colonies were screened for selection of putative mutants. Among several mutants, one mutant (whose mycelia) produced a larger amount of L-DOPA form L-tyrosine was selected and designated mutant SI-12. The mutant was picked up and transferred to potato dextrose agar slants for maximum sporulation and stored in cold room at $4^{\circ} \mathrm{C}$.

\section{Batch-culture studies}

Organisms were grown on glucose, sucrose, maltose, xylose, lactose and glycerol $\left(3.0 \%\right.$, w. $\left.\mathrm{w}^{-1}\right)$ media to produce L-DOPA in basal Vogel's salts medium ( $\mathrm{pH}_{\mathrm{o}} 5.0$, unless otherwise stated). Different nitrogen sources $\left[\mathrm{NH}_{4} \mathrm{Cl},\left(\mathrm{NH}_{4}\right)_{2} \mathrm{HPO}_{4},\left(\mathrm{NH}_{2}\right)_{2} \mathrm{CO}\right.$, $\left(\mathrm{NH}_{4}\right)_{2} \mathrm{SO}_{4}, \mathrm{NH}_{4} \mathrm{NO}_{3}$ and $\left.\mathrm{NaNO}_{3}\right]$ were also evaluated in the same medium. All media were dispensed in $40 \mathrm{~mL}$ aliquots into 250-mL Erlenmeyer flasks in triplicate and autoclaved. Inoculum (5.0 mg dry cells per $5.0 \mathrm{~mL}$ ) was added aseptically to all the media.

Time course of L-DOPA production in shake-flask cultures was carried out at $30^{\circ} \mathrm{C}$ (unless otherwise stated) in a rotary shaking incubator (100 rpm). Sample flasks in triplicate were withdrawn after predetermined time intervals and processed. The culture medium after growth was centrifuged (10 min, 15000 g) to collect cell mass (from $40 \mathrm{~mL}$ portion). Dry cell biomass concentration in the fermentation broth and inocula was measured by dry weight filtering $40 \mathrm{~mL}$ samples (in triplicate) o9n $0.45 \mu \mathrm{m}$ membrane filters. The cell pellets were washed twice with saline water, and dried at $70^{\circ} \mathrm{C}$ to a constant mass. The enzyme activity present in the wet cells from $10 \mathrm{~mL}$ samples was assayed (17).

\section{Effect of different nitrogen sources on L-DOPA production}

The effect of different nitrogen sources (Table 3) to give equimolar nitrogen content $\left(1.2 \mathrm{~g} . \mathrm{L}^{-1}\right.$ as contained in $\left(\mathrm{NH}_{4}\right)_{2} \mathrm{SO}_{4}$ and $\mathrm{NH}_{4} \mathrm{NO}_{3}$ ) was observed while maintaining other variables constant. The concentration of L-DOPA formed was measured at $55^{\circ} \mathrm{C}$ in intact wet cells.

\section{Reaction procedure}

The reaction for L-DOPA production from L-tyrosine was carried out using a suspension of intact mycelium after Haneda et al. (10). The reaction was carried out in buffered solution $(\mathrm{pH}$ 3.5) under reduced condition at $55^{\circ} \mathrm{C}$ for $60 \mathrm{~min}$ (12), and LDOPA formed was measured. For the determination of activation energy for transformation of 1.0 M tyrosine to L-DOPA by tyrosinase, the repeat reactions were carried out at different temperatures $\left(35,40,45,50,60,65\right.$, and $\left.70^{\circ} \mathrm{C}\right)$ and maximum enzyme $\left(\mathrm{V}_{\max }\right)$ activity at relevant temperature was measured. One unit of activity was defined as the amount of enzyme required to form $1.0 \mu \mathrm{M}$ L-DOPA per millilitre of enzyme preparation in $60 \mathrm{~min}$ reaction time under the experimental conditions. Arrhenius relationship, $\mathrm{Ln}_{\max }=-\mathrm{E}_{\mathrm{a}} / \mathrm{RT}$, was used to calculate the activation energy. To find out specific product 
formation rate at above temperatures, the reaction was carried out at relevant temperature at $0.16,0.33,0.5,0.75,0.92,1.0,1.08$, $1.17,1.25,1.5,1.75 \mathrm{~h}$ of reaction time and L-DOPA formed $(\mathrm{mg})$ per gram cells was plotted against reaction time. The slopes gave the values of specific product formation rate $\left(\mathrm{q}_{\mathrm{p}}\right)$ at respective reaction temperature. These data were used to calculate thermodynamic parameters.

\section{Estimation of L-DOPA}

L-DOPA was determined by the method of Arnow (4). One millilitre of unknown solution (containing 0.02 to $1.0 \mathrm{mg}$ of L-DOPA) and $75 \mathrm{mg}$ of mycelial cells (15 mg dry cells) were added in a graduated test tube. Standard solution was treated in the same way. To each tube, following reagents were added: $1.0 \mathrm{~mL}$ of $0.5 \mathrm{~N}$ hydrochloric acid and $1.0 \mathrm{~mL}$ of nitrate molybdate reagent. This gave a yellow colour. One millilitre of $1.0 \mathrm{~N} \mathrm{NaOH}$ was added in the test tube (a red colour was formed). Water was, then, added to make a final working volume of $5.0 \mathrm{~mL}$. All readings were taken in triplicate. The results were compared using spectrophotometer.

\section{Estimation of tyrosine}

Tyrosine was estimated after Arnow (4). One millilitre of unknown tyrosine solution (containing $0.05-0.15 \mathrm{mg}$ of tyrosine) was added in a $5.0 \mathrm{~mL}$ graduated test tube. Standard solution was placed in a similar way. To each tube, $1.0 \mathrm{~mL}$ of mercuric sulphate reagent (15 g dissolved in $100 \mathrm{~mL}$ of sulphuric acid) was added. After well mixing, both tubes were placed in a boiling water bath for $10 \mathrm{~min}$ in triplicate. The mixture was cooled and to each tube, $1.0 \mathrm{~mL}$ of nitrate reagent $(0.2 \%$, w/v aqueous solution) was added. Distilled water was added to the tubes to make $5.0 \mathrm{~mL}$ working volume. In the presence of L-DOPA, the mixture was turbid. The mixture was centrifuged to remove L-DOPA. Three to four millilitre of clear, red supernatant was pipetted off and compared with the standard in colorimeter.

\section{Effect of varying $\mathrm{pH}$ and temperature on L-DOPA production}

The effect of initial $\mathrm{pH}_{0}$ of the fermentation medium on LDOPA production was studied in shake flasks by varying $\mathrm{pH}_{\mathrm{o}}$ (5.0-7.5) and maintaining optimum temperature and other growth supporting conditions. Wet biomass attained after filtration was used to produce L-DOPA at $55^{\circ} \mathrm{C}$ as described above. For studying the effect of temperature on cell mass formation and tyrosinase production in intact mycelia, the experiments were repeated in shake flasks (as above) and incubated in an orbital shaker (100 rpm) at 20, 22, 24, 26, 28, 30, 32, 34, 36 and $38^{\circ} \mathrm{C}$ for up to a period of $72 \mathrm{~h}$. the preparations were analyzed for DOPA formation at $55^{\circ} \mathrm{C}$.

\section{Saccharide and protein determination}

Saccharides were analyzed by HPLC (Perkin Elmer, USA). The separation was achieved by using organic acid column
(HPX-87H ion exchange column 300×78 mm, Bio-Richmond, California, USA) maintained at $45^{\circ} \mathrm{C}$ in a column oven. Sulphuric acid $(0.002 \mathrm{~N})$ in HPLC grade water served as a mobile phase at $0.6 \mathrm{~mL} \cdot \mathrm{min}^{-1}$. The samples were detected using refractive index detector and quantified using Turbochron4 software of Perkin Elmer, USA. Protein was determined after Bradford using bovine serum albumin as standard.

\section{Determination of kinetic parameters}

All kinetic parameters were determined after Lawford and Rousseau (14). Volumetric rate of L-DOPA produced $\left(\mathrm{Q}_{\mathrm{p}}\right)$ was determined from a plot between L-DOPA (mg.L $\left.\mathrm{L}^{-1}\right)$ and time of fermentation, process product yield $\left(\mathrm{Y}_{\mathrm{p} / \mathrm{s}}\right)$ was determined from $\mathrm{dP} / \mathrm{dS}$, specific product yield ( $\mathrm{Y}_{\mathrm{p} / \mathrm{x}}, \mathrm{mg} . \mathrm{g}^{-1}$ cells) was determined using relationship $\left(\mathrm{dP}^{\mathrm{d}} \cdot \mathrm{dX}^{-1}\right)$ and specific rate of product formation $\left(\mathrm{q}_{\mathrm{p}}\right)$ was determined using $\mathrm{Y}_{\mathrm{p} / \mathrm{x}} \times \mu$ (specific growth rate). Specific growth rate was determined as slope of straight line between $\operatorname{LnX}\left(\mathrm{X}=\right.$ cell mass, $\left.\mathrm{g} . \mathrm{L}^{-1}\right)$ and time of fermentation (h) using relationship $\mu \mathrm{t}=\operatorname{Ln} \mathrm{X}$.

\section{Statistical analysis}

Treatment effects were compared by the protected least significant difference method (20) and have been presented as two-factor design in the form of probability (p) using MstatC software.

\section{RESULTS AND DISCUSSION}

\section{Screening of mutant of Aspergillus oryzae}

Aspergillus oryzae strain UV-7 was mutated using mutagenesis with NTG. Overall, wild strain, best UV mutant and 12 double mutants were grown in submerged fermentation to produce fungal mycelia. Seventy five milligram of mycelium (wet weight, $15 \mathrm{mg}$ dry weight) was used in reaction mixture (buffered medium, $\mathrm{pH} 3.5+\mathrm{L}$-ascorbic acid) containing L-tyrosine and incubated at $55^{\circ} \mathrm{C}$ for $60 \mathrm{~min}$. The data of Table 1 show the production of L-DOPA by different putative mutant strains compared with the wild and UV-derived mutant. The double mutant strain of Aspergillus oryzae SI-12 gave maximum production of L-DOPA ( $300 \mathrm{mg} . \mathrm{g}^{-1}$ dry cells) and was significantly improved over some putative mutants. A. oryzae SI-12, being the best producer of L-DOPA, was selected for further investigations.

\section{Effect of different carbon sources}

The effect of different carbon sources (glucose, sucrose, maltose, xylose, lactose, and glycerol) on the production of LDOPA from L-tyrosine is shown in Table 2. Best yield of LDOPA (300 mg. $\mathrm{g}^{-1}$ cells, $150 \mathrm{mg} . \mathrm{g}^{-1}$ glucose utilized, $125 \mathrm{mg} . \mathrm{l}^{-1}$. $\mathrm{h}^{-1}, 150 \mathrm{mg} \cdot \mathrm{g}^{-1}$ cells h$^{-1}$, respectively) was obtained when glucose was used as a carbon source in the mycelium production medium and the tyrosinase activity increased constitutively which 
Table 1. Screening of putative mutants of Aspergillus oryzae UV-7 obtained by chemical mutagenesis.

\begin{tabular}{lcc}
\hline A. oryzae strains & \multicolumn{2}{c}{ L-DOPA production kinetic parameters } \\
\cline { 2 - 3 } & \multicolumn{1}{c}{$\mathrm{Y}_{\mathrm{p} / \mathrm{x}}\left(\mathrm{mg} . \mathrm{g}^{-1}\right.$ cells $) \mathrm{Y}_{\mathrm{p} / \mathrm{s}}\left(\mathrm{mg} \cdot \mathrm{g}^{-1}\right.$ substrate $)$} \\
\hline Parent & $79.5 \pm 3.5^{\mathrm{h}}$ & $40.0 \pm 2^{\mathrm{j}}$ \\
UV-mutant & $120.0 \pm 6^{\mathrm{g}}$ & $59.0 \pm 3^{\mathrm{i}}$ \\
Mutants isolated & \multicolumn{2}{c}{ through chemical mutagenesis } \\
S1-2 & $256.0 \pm 12^{\mathrm{c}}$ & $129.0 \pm 6^{\mathrm{d}}$ \\
S1-3 & $296.0 \pm 14^{\mathrm{a}}$ & $148.0 \pm 7^{\mathrm{bc}}$ \\
S1-7 & $298.0 \pm 16^{\mathrm{a}}$ & $150.0 \pm 8^{\mathrm{a}}$ \\
S1-8 & $286.0 \pm 13^{\mathrm{b}}$ & $144.0 \pm 7^{\mathrm{b}}$ \\
S1-9 & $280.0 \pm 14^{\mathrm{b}}$ & $142.0 \pm 13^{\mathrm{c}}$ \\
S1-10 & $228.0 \pm 12^{\mathrm{de}}$ & $113.5 \pm 6^{\mathrm{g}}$ \\
S1-11 & $218.5 \pm 12^{\mathrm{f}}$ & $110.0 \pm 5^{\mathrm{h}}$ \\
S1-12 & $302.0 \pm 14^{\mathrm{a}}$ & $151.0 \pm 7^{\mathrm{a}}$ \\
S1-16 & $224.0 \pm 12^{\mathrm{ef}}$ & $122.0 \pm 6^{\mathrm{e}}$ \\
S1-18 & $234.0 \pm 12^{\mathrm{d}}$ & $117.0 \pm 7^{\mathrm{f}}$ \\
LSD at $\mathrm{p} \leq 0.05$ & 6.14 & 1.62 \\
Significance at $\mathrm{p} \leq 0.05$ & $\mathrm{HS}$ & $\mathrm{HS}$ \\
\hline
\end{tabular}

Values followed by different letters differ significantly at $\mathrm{p} \leq 0.05$. $\mathrm{Y}_{\mathrm{p} / \mathrm{s}}$ $=$ product yield (mg DOPA. $\mathrm{g}^{-1}$ substrate utilized). $\mathrm{Y}_{\mathrm{p} / \mathrm{x}}=$ specific product yield (mg DOPA. $\mathrm{g}^{-1}$ cells).

resulted in greater production of L-DOPA. It differed significantly $(\mathrm{p} \leq 0.05)$ with the all other carbon sources. During growth on glucose culture medium, enhanced production of L-DOPA occurred due to the enhanced tyrosinase activity, which converted tyrosine in to L-DOPA. Minimum production was obtained with glycerol $\left(50 \mathrm{mg} \cdot \mathrm{g}^{-1}\right.$ cells with volumetric productivity of $\left.1.0 \mathrm{mg} \cdot \mathrm{L}^{-1} \cdot \mathrm{h}^{-1}\right)$ in case of mutated cells. This occurred due to low terminal $\mathrm{pH}$ of the fermentation medium $(\mathrm{pH} 2.5)$ at which both the enzyme activity and product were degraded. This study is in good agreement with that of Raju et al. (22) who also found glucose to be the best carbon source to provoke maximum production of mycelia and tyrosinases. In other enzyme systems, disaccharides or higher molecular weight substrates have been found to be the best supporters of the enzymes $(20,21)$. It can be concluded that tyrosinase is a constitutive enzyme and mutagensis gave rise to a mutant, which was further altered with respect to production of tyrosinases in the presence of glucose.

\section{Effect of different nitrogen sources}

The effect of different nitrogen sources namely $\mathrm{NH}_{4} \mathrm{Cl}$, $\mathrm{NH}_{4} \mathrm{NO}_{3},\left(\mathrm{NH}_{4}\right)_{2} \mathrm{HPO}_{4},\left(\mathrm{NH}_{2}\right)_{2} \mathrm{CO},\left(\mathrm{NH}_{4}\right)_{2} \mathrm{SO}_{4}, \mathrm{NaNO}_{3}$ (to give equimolar amount of nitrogen maintained at $1.24 \mathrm{~g} . \mathrm{L}^{-1}$ ) on the production of L-DOPA from L-tyrosine using the fungal mycelium as the source of fungal tyrosinase, indicated that readily available nitrogen sources like $\mathrm{NH}_{4}$ salts were the best
Table 2. Screening of putative mutants of Aspergillus oryzae UV-7 obtained by chemical mutagenesis.

\begin{tabular}{|c|c|c|c|c|}
\hline \multirow{2}{*}{$\begin{array}{l}\text { Substrate/ } A . \\
\text { A. oryzae } \\
\text { strains }\end{array}$} & \multicolumn{4}{|c|}{ L-DOPA production kinetic parameters } \\
\hline & $\begin{array}{c}\mathrm{Yp} / \mathrm{x} \\
\left(\mathrm{mg} \cdot \mathrm{g}^{-1}\right. \\
\text { cells) }\end{array}$ & $\begin{array}{c}\mathrm{Yp} / \mathrm{s} \\
\left(\mathrm{mg} \cdot \mathrm{g}^{-1}\right. \\
\text { substrate) }\end{array}$ & $\begin{array}{c}\text { Qp } \\
\left(\mathrm{mg} \cdot \mathrm{l}^{-1} \cdot \mathrm{h}^{-1}\right)\end{array}$ & $\begin{array}{c}\text { Qp } \\
\left(\mathrm{mg} \cdot \mathrm{g}^{-1}\right. \\
\left.\text { cells. } \mathrm{h}^{-1}\right)\end{array}$ \\
\hline \multicolumn{5}{|l|}{ Glucose } \\
\hline Parent & $80 \pm 4^{\mathrm{e}}$ & $41 \pm 2^{\mathrm{g}}$ & $40 \pm 2^{\mathrm{d}}$ & $38 \pm 2^{\mathrm{f}}$ \\
\hline $\begin{array}{l}\text { Mutant SI-12 } \\
\text { Glycerol }\end{array}$ & $300 \pm 14^{\mathrm{a}}$ & $150 \pm 8^{a}$ & $126 \pm 5^{a}$ & $149 \pm 8^{a}$ \\
\hline$\overline{\text { Parent }}$ & $15 \pm 1^{\mathrm{j}}$ & $8 \pm 0.5^{1}$ & $6 \pm 0.5^{j}$ & $6 \pm 0.2^{i}$ \\
\hline $\begin{array}{l}\text { Mutant SI-12 } \\
\text { Xylose }\end{array}$ & $50 \pm 2^{i}$ & $26 \pm 1^{\mathrm{k}}$ & $21 \pm 1^{\mathrm{h}}$ & $21 \pm 1^{\mathrm{h}}$ \\
\hline$\overline{\text { Parent }}$ & $70 \pm 3^{\mathrm{h}}$ & $34 \pm 1^{\mathrm{j}}$ & $24 \pm 1^{\mathrm{f}}$ & $24 \pm 1^{\mathrm{h}}$ \\
\hline $\begin{array}{l}\text { Mutant SI-12 } \\
\text { Lactose }\end{array}$ & $234 \pm 12^{\mathrm{d}}$ & $125 \pm 5^{\mathrm{d}}$ & $80 \pm 3^{b}$ & $85 \pm 4^{c}$ \\
\hline Parent & $74 \pm 2^{\mathrm{g}}$ & $43 \pm 2^{\mathrm{f}}$ & $12 \pm 1^{\mathrm{i}}$ & $32 \pm 2^{g}$ \\
\hline $\begin{array}{l}\text { Mutant SI-12 } \\
\text { Sucrose }\end{array}$ & $238 \pm 13^{c}$ & $136 \pm 6^{c}$ & $40 \pm 2^{\mathrm{e}}$ & $99 \pm 4^{\mathrm{c}}$ \\
\hline$\overline{\text { Parent }}$ & $75 \pm 2^{g}$ & $38 \pm 2^{\mathrm{h}}$ & $25 \pm 1^{\mathrm{e}}$ & $30 \pm 1^{\mathrm{g}}$ \\
\hline $\begin{array}{l}\text { Mutant SI-12 } \\
\text { Maltose }\end{array}$ & $238 \pm 13^{c}$ & $138 \pm 6^{b}$ & $80 \pm 4^{b}$ & $94 \pm 2^{d}$ \\
\hline Parent & $78 \pm 1^{\mathrm{f}}$ & $36 \pm 1^{\mathrm{i}}$ & $22 \pm 1^{\mathrm{g}}$ & $32 \pm 1^{\mathrm{g}}$ \\
\hline Mutant SI-12 & $267 \pm 13^{b}$ & $116 \pm 6^{\mathrm{e}}$ & $72 \pm 2^{c}$ & $104 \pm 2^{b}$ \\
\hline $\begin{array}{l}\text { LSD at } \\
\mathrm{P}>0.05\end{array}$ & 1.91 & 0.924 & 0.704 & 3.129 \\
\hline $\begin{array}{l}\text { Significance at } \\
\mathrm{P}>0.05\end{array}$ & HS & HS & HS & HS \\
\hline
\end{tabular}

Each value is an average of three replicates. \pm indicates standard deviation among replicated.

The values followed by different letters differ significantly at $\mathrm{p}>$ 0.05. For this purpose, ANOVA was applied. The effect of treatments was highly significant. $\mathrm{Y}_{\mathrm{p} / \mathrm{s}}=$ product yield (mg. DOPA. $\mathrm{g}^{-1}$ substrate utilized), $\mathrm{Yp} / \mathrm{x}=$ specific product yield (mg DOPA. g. cells), $\mathrm{Qp}=$ Volumetric rate of product formation (mg. DOPA. $\left.\mathrm{l}^{-1} \cdot \mathrm{h}^{-1}\right), \mathrm{qp}=\left(\mathrm{mg} \cdot \mathrm{g}^{-1}\right.$ cells. $\left.\mathrm{h}^{-1}\right)$.

inducers of tyrosinase synthesis unlike other systems e.g., production of $\beta$-glucosidase by Kluyveromyces marxianus (Our unpublished results) in which nitrogen sources like urea and corn steep liquor supported maximum production of enzyme. $\mathrm{NH}_{4} \mathrm{NO}_{3}, \mathrm{NaNO}_{3}$ were the poor inducers of tyrosinase compared against other ammonium salts (Table 3 ). In other systems, $\mathrm{NaNO}_{3}$ proved to be the best nitrogen source due to the presence of high nitrate reductase activity in such systems $(20,21)$. Use of $\mathrm{NH}_{4} \mathrm{Cl}$ as a nitrogen source gave the maximum production of $189 \mathrm{mg}$ L-DOPA. $\mathrm{g}^{-1}$ glucose utilized (equivalent to $441 \mathrm{mg} \mathrm{L}$ DOPA. $\mathrm{g}^{-1}$ dry mycelium). However, with other nitrogen sources, L-DOPA production decreased systematically with increase in complexity. Minimum production was obtained with $\mathrm{NaNO}_{3}$ 
Table 3. Effect of nitrogen sources on DOPA production by Aspergillus niger SA1-12 grown on glucose medium.

\begin{tabular}{lcccc}
\hline N-sources & \multicolumn{3}{c}{ L-DOPA production kinetic parameters } \\
\cline { 2 - 5 } & $\begin{array}{c}\text { Yp/x } \\
\left(\mathrm{mg} \cdot \mathrm{g}^{-1}\right. \\
\text { cells })\end{array}$ & $\begin{array}{c}\text { Yp/s } \\
\left(\mathrm{mg} \cdot \mathrm{g}^{-1}\right. \\
\text { substrate })\end{array}$ & $\begin{array}{c}\text { Qp } \\
\left(\mathrm{mg} . \mathrm{l}^{-1} \cdot \mathrm{h}^{-1}\right)\end{array}$ & $\begin{array}{c}\text { Qp } \\
\left(\mathrm{mg} . \mathrm{g}^{-1}\right. \\
\left.\text { cells. } \mathrm{h}^{-1}\right)\end{array}$ \\
\hline $\mathrm{Control}$ & $300 \pm 14^{\mathrm{e}}$ & $151 \pm 8^{\mathrm{b}}$ & $126 \pm 6^{\mathrm{e}}$ & $151 \pm 8^{\mathrm{e}}$ \\
$\mathrm{NH}_{4} \mathrm{Cl}$ & $441 \pm 20^{\mathrm{a}}$ & $189 \pm 9^{\mathrm{a}}$ & $145 \pm 7^{\mathrm{a}}$ & $214 \pm 10^{\mathrm{a}}$ \\
$\left(\mathrm{NH}_{4}\right)_{2} \mathrm{HPO}_{4}$ & $406 \pm 16^{\mathrm{b}}$ & $133 \pm 6^{\mathrm{c}}$ & $133 \pm 6^{\mathrm{b}}$ & $157 \pm 8^{\mathrm{b}}$ \\
$\left(\mathrm{NH}_{2}\right)_{2} \mathrm{CO}$ & $364 \pm 15^{\mathrm{c}}$ & $132 \pm 7^{\mathrm{c}}$ & $131 \pm 7^{\mathrm{c}}$ & $153 \pm 8^{\mathrm{d}}$ \\
$\mathrm{NH}_{4} \mathrm{NO}_{3}$ & $357 \pm 18^{\mathrm{d}}$ & $129 \pm 8^{\mathrm{d}}$ & $129 \pm 8^{\mathrm{d}}$ & $155 \pm 9^{\mathrm{c}}$ \\
$\mathrm{NaNO}_{3}$ & $285 \pm 14^{\mathrm{f}}$ & $118 \pm 5^{\mathrm{e}}$ & $106 \pm 5^{\mathrm{f}}$ & $127 \pm 6^{\mathrm{f}}$ \\
$\mathrm{LSD}_{\mathrm{at}}$ & $267 \pm 14^{\mathrm{g}}$ & $106 \pm 5^{\mathrm{f}}$ & $100 \pm 4^{\mathrm{g}}$ & $120 \pm 4^{\mathrm{g}}$ \\
$\mathrm{P}>0.05$ & & & & \\
Significance at & 2.441 & 1.590 & 1.471 & 1.890 \\
$\mathrm{P}>0.05$ & $\mathrm{HS}$ & $\mathrm{HS}$ & $\mathrm{HS}$ & $\mathrm{HS}$ \\
\hline
\end{tabular}

Each value is an average of three replicates. \pm indicates standard deviation among replicated.

The values followed by different letters differ significantly at $\mathrm{p}>0.05$. For this purpose, ANOVA was applied. The effect of treatments was highly significant. Values for parental cultures have not been presented. In all cases, the mutant was improved over its parental culture by 3.0 to 3.8 -fold.

(114 mg. $\mathrm{g}^{-1}$ glucose utilized, equivalent to $267 \mathrm{mg}$ L-DOPA. $\mathrm{g}^{-1}$ cells). $\mathrm{NH}_{4} \mathrm{Cl}$ was found to be the best source of nitrogen because it was easy for mycelium to get nitrogen from this source. In the presence of more available nitrogen, the mycelium grew better and its activity also increased constitutively. Raju et al. (17) also obtained maximum production of L-DOPA using $\mathrm{NH}_{4} \mathrm{Cl}$ as the nitrogen source. Similarly other workers (15) also found ammonium chloride as best stimulator of cell mass and L-DOPA production. The highest volumetric productivity $\left(\mathrm{Q}_{\mathrm{p}}, 145 \mathrm{mg} \cdot \mathrm{L}^{-1}\right.$ $\mathrm{h}^{-1}$ ) of L-DOPA is several fold higher than the values reported on other organisms $(9,10,11,13,17,22,25)$, Escherichia coli recombinants $(15,16)$ and immobilized tyrosinase with productivity level of $53.97 \mathrm{mg} . \mathrm{L}^{-1} \mathrm{~h}^{-1}(5)$.

\section{Effect of initial $\mathrm{pH}\left(\mathrm{pH}_{0}\right)$ of medium and temperature of fermentation on L-DOPA production}

Optimum $\mathrm{pH}_{0}$ for maximum volumetric and specific productivity of cell mass, tyrosinase production in intact mycelia, which led to the enhanced L-DOPA biosynthesis in a reaction mixture incubated at $55^{\circ} \mathrm{C}$ was 5.0. (Fig. 1) and coincides with the optimum reported in the literature for this organism in synthetic medium. Further alteration in $\mathrm{pH}$ of fermentation medium had substantial influence on the productivities of enzymes in intact mycelia (which supported production of LDOPA in the reaction mixture) and metabolic shift to alternative

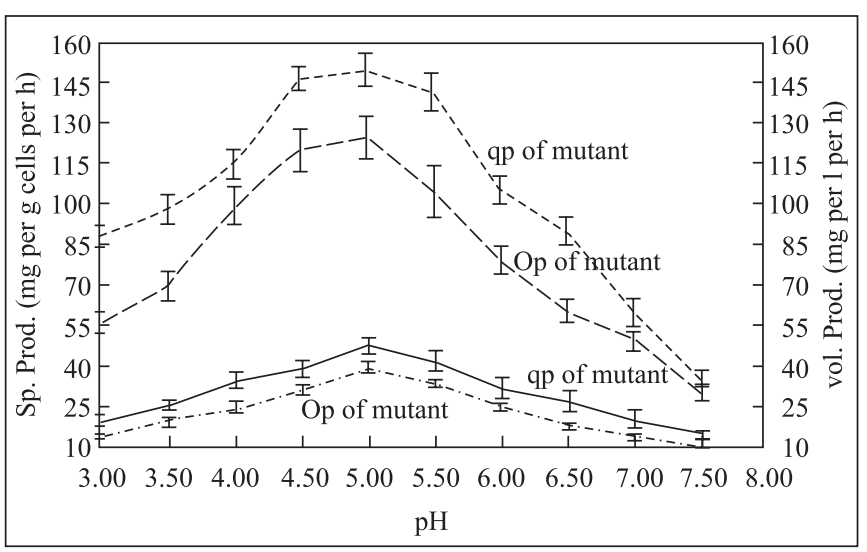

Figure 1. Effect of initial $\mathrm{pH}\left(\mathrm{pH}_{0}\right)$ of the fermentation medium on the product formation rate of L-DOPA $\left(\mathrm{Q}_{\mathrm{p}}\right)$ and its specific productivity $\left(\mathrm{q}_{\mathrm{p}}\right)$ from L-tyrosine by parental and mutant cultures.

glucose utilization ways occurred. Under all $\mathrm{pH}$ values of the fermentation medium, the carbon source was consumed for production of cell mass and other products. Cell growth varied according to the $\mathrm{pH}_{\mathrm{o}}$ of the synthetic medium with maximum being achieved at optimum $\mathrm{pH}_{\mathrm{o}}$ of the medium. At extreme $\mathrm{pH}_{\mathrm{o}}$ values, growth was affected severely and resulted in lower tyrosinase activity and hence L-DOPA production. Similar behavior was displayed by the enzyme in reaction mixture (optimum $\mathrm{pH}$ 3.5). This work substantiates the findings of Haneda et al. (10) and Raju et al. (22). Olsen (18) obtained maximum production of L-DOPA at $\mathrm{pH} 6.0$ of medium while Evans and Rapers (9) found maximum production of L-DOPA in a medium of $\mathrm{pH} 6.5$.

Maximum productivity of growth and tyrosinase production occurred at fermentation temperature of $30^{\circ} \mathrm{C}$ and supported maximum volumetric $\left(\mathrm{Q}_{\mathrm{p}}\right)$ and specific $\left(\mathrm{q}_{\mathrm{p}}\right)$ productivities of L-DOPA (Fig. 2) in the reaction mixture maintained at a reaction temperature of $55^{\circ} \mathrm{C}$. This figure shows that this bioprocess for cell mass production and tyrosinase production could be quantitatively carried out over a wide range of temperature. Maximum cell mass produced supported maximum L-DOPA production in the reaction mixture. At extreme high or low temperature, tyrosinase production by the cells was suppressed. This probably was attributed to increase sensitivity of cell growth to thermal inactivation. Slow rate of product formation at low temperature was due to the fact that activity of enzyme produced is directly related to the temperature. Moreover, at lower temperature, the transport of substrate across the mycelia was suppressed and attained lower yield of enzyme, which converted less amount of tyrosine to L-DOPA in the reaction mixture for L-DOPA production. At higher temperature, the requirement of maintenance energy for the cell was high which was attributed to thermal denaturation of other enzymes of the 


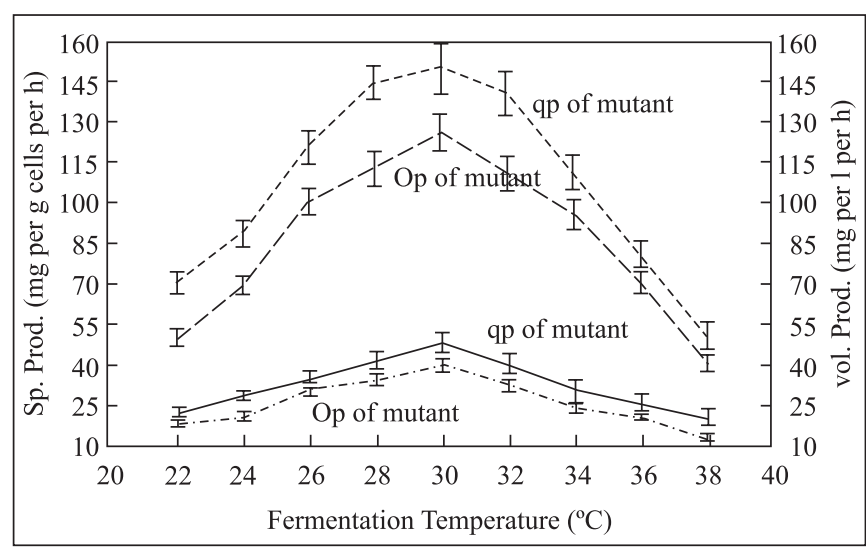

Figure 2. Maximum productivity values of 3,4dihydroxyphenylalanine (L-DOPA) measured as $\mathrm{Q}_{\mathrm{p}}(\mathrm{mg} \mathrm{L}-$ DOPA. $\mathrm{l}^{-1} \cdot \mathrm{h}^{-1} \mathrm{mg}$ ) and specific productivity, $\mathrm{q}_{\mathrm{p}}$ (mg L-DOPA. $\mathrm{g}^{-1}$ cells. $\mathrm{h}^{-1}$ ) from glucose medium, carried out at different temperatures by parental and mutant cultures.

metabolic pathway or tyrosinase and hence the production was minimum. Maximum activity in bacteria was obtained around neutral $\mathrm{pH}$ of the medium and temperature $30^{\circ} \mathrm{C}$ but fungi vary with respect to $\mathrm{pH}$ and temperature optima to support maximum production of enzymes and other products $(20,21)$.

The activity of tyrosinase for production of L-DOPA from Ltyrosine at $35^{\circ} \mathrm{C}$ was $9 / 1 \mathrm{IU} . \mathrm{mL}^{-1} \cdot \mathrm{h}^{-1}$ and increased substantially with increase in temperature of reaction mixture up to a maximum of $22.8 \mathrm{IU} . \mathrm{mL}^{-1} \cdot \mathrm{h}^{-1}$ at reaction temperature of $55^{\circ} \mathrm{C}$. Further perturbation in temperature of reaction mixture, resulted in dramatic reduction in the enzyme activity. Abatement in the activity beyond $55^{\circ} \mathrm{C}$ may be due to the thermal denaturation of tyrosinases or decomposition of L-tyrosine and L-DOPA, to other metabolites. But this was encouraging that enzyme system was thermodynamically resistant to denaturation at elevated temperatures as was visualized by the application of Arrhenius approach $\left(\operatorname{LnV}_{\max }=-\mathrm{E}_{\mathrm{a}} / \mathrm{RT}\right)$. Activation energy requirement for conversion of $1.0 \mathrm{M}$ tyrosine to L-DOPA was $37.6 \mathrm{k} \mathrm{j} / \mathrm{mol}$ while for deactivation of tyrosinase its respective value was $80.8 \mathrm{kj} /$ mol (calculated from Fig. 3) while corresponding value for the parental system were 51.6 and $74.8 \mathrm{k} \mathrm{J} / \mathrm{mol}$, respectively. These studies revealed that the enzyme was fairly thermostable.

\section{Thermodynamics of L-DOPA production}

It has been demonstrated (6) that both volumetric and specific productivities can be used to determine the thermodynamic parameters of all microbial processes provided that a sufficient number of data at different temperatures is available. Specific productivities at different temperatures were used to calculate thermodynamic parameters for L-DOPA production and its deactivation. Maximum L-DOPA-specific or

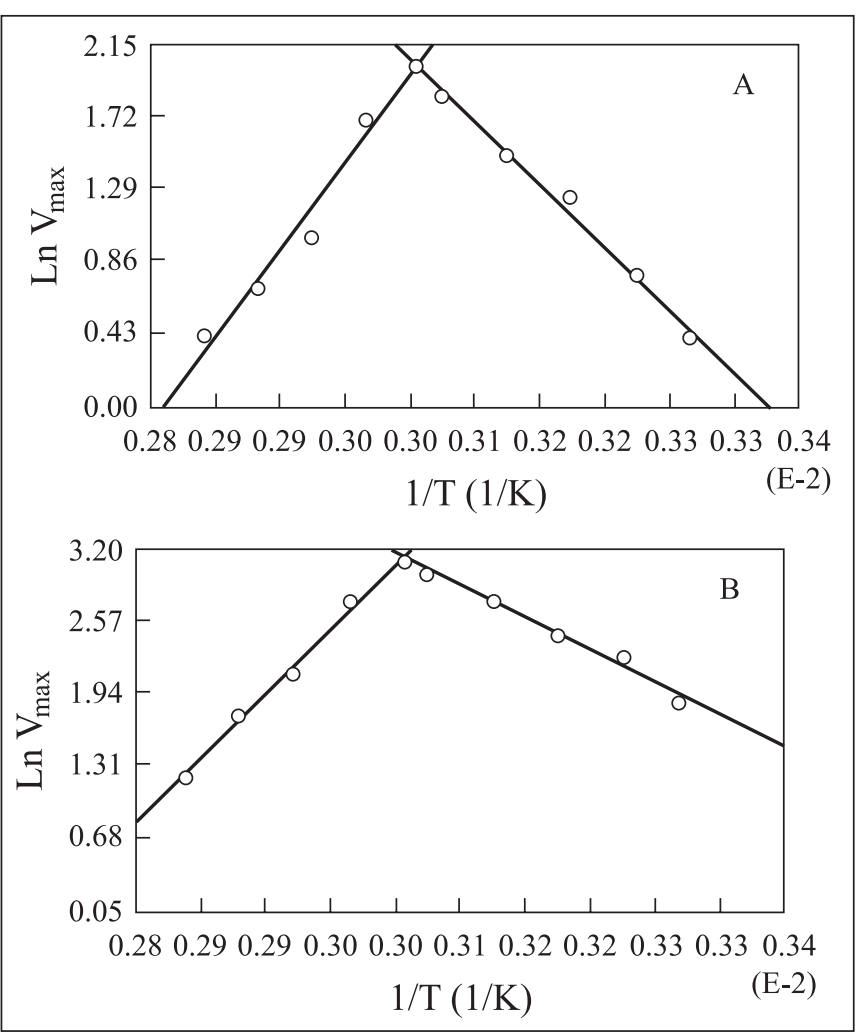

Figure 3. Application of Arrhenius model to calculate activation energy for L-DOPA production by tyrosinase immobilized in fungal mycelium and its thermal deactivation: parental (A) and mutant (B) cultures.

-volumetric productivity actually increases with the increase in temperature up to a threshold value $\left(\right.$ at $\left.30^{\circ} \mathrm{C}\right)$ after which a sharp decrease was observed due to the thermal inactivation (Fig. 3)

Empirical approach of Arrhenius (1) was used to describe the relationship for temperature dependent reversible and irreversible inactivation of tyrosinase. Beside this approach, two different thermodynamic models were proposed to elucidate the thermal inactivation of enzyme systems. The "thermodynamic approach" was used by Roels (24) to describe the incidence of temperature dependent reversible inactivation on the kinetics of enzymatic systems. On the other hand, "kinetic approach" (1) was only useful to describe the time dependent phenomena of irreversible inactivation and thermal death of cells. For these reasons, the activation enthalpy of L-DOPA production was graphically calculated by the application of Arrhenius approach extended to microbial processes (24). For this purpose, $\operatorname{Kr}(1)$ was replaced by $\mathrm{q}_{\mathrm{p}}$ (specific productivity) values with which following relationship was developed:

$$
\begin{aligned}
& \mathrm{q}_{\mathrm{p}}=\mathrm{T} \cdot \mathrm{k}_{\mathrm{B}} / \mathrm{h} \mathrm{e}^{\Delta \mathrm{S}^{*} / \mathrm{R}} \mathrm{e}^{\Delta \mathrm{H}^{*} / \mathbb{R} . \mathrm{T}} \\
& \mathrm{Ln} \_\left(\mathrm{q}_{\mathrm{p}} / \mathrm{T}\right)=\mathrm{Ln}\left(\mathrm{k}_{\mathrm{B}} / \mathrm{h}\right)+{ }_{\Delta} \mathrm{S} * / \mathrm{R}{ }_{-} \mathrm{H}^{*} / \mathrm{R} \cdot 1 / \mathrm{T}
\end{aligned}
$$


Where $\mathrm{T}$ is absolute temperature, $\mathrm{k}_{\mathrm{B}}$ is Botzmann constant, $\mathrm{h}$ is Planck's constant, ${ }_{\Delta} \mathrm{S}^{*}$ is entropy of activation. $\Delta \mathrm{H}^{*}$ is enthalpy $\mathrm{f}$ activation and $\mathrm{R}$ is gas constant.

The values of the thermodynamic parameters estimated with above model form Fig. 4 has been summarized in Table 4 . Activation enthalpy of L-DOPA formation by mutant SA-12 $\left({ }_{\Delta} \mathrm{H}^{*}=40 \mathrm{k} \mathrm{j} / \mathrm{mol}\right)$ is lower than that for phytase production (70-80 k j/mol) reported by Al-Asheh and Duvniak (2) but compares favorably with those estimated for many different whole-cell bioprocesses, such as cell growth $(34-74 \mathrm{~kJ} / \mathrm{mol})(1,3)$.

The phenomena responsible for thermal inactivation of enzyme is characterized by and activation enthalpy $\left({ }_{\Delta} \mathrm{H}_{\Delta} *=116\right.$ $\mathrm{kJ} / \mathrm{mol}$ ) and is remarkably higher that that for L-DOPA production. It means that its rate decreases much faster with temperature than product formation rate. Therefore, the overall productivities fall sharply above as threshold value (Fig. 3). The value of ${ }_{\Delta} \mathrm{H}_{\mathrm{D}} *$ is significantly lower than the values reported for many enzymatic systems $(160-235 \mathrm{~kJ} / \mathrm{mol})(1,2,6)$. This suggests that the productivities decrease observed at high temperature could be due to the reversible denaturation of enzyme formed during growth of the organism on glucose.

The activation entropy of L-DOPA formation $(-0.076 \mathrm{~kJ} / \mathrm{mol}$ $\mathrm{K})$ is very low and compares favorably with that of glucose isomerase reaction (6) and other fermentation processes $(3,7)$. As these values are consistent with the values for formation of a transition state with more rigid structure with respect to the reacting system, they further lead to suggest that the phenomenon limiting L-DOPA production could be an enzymatic reaction under all varying fermentation conditions as observed for xylitol production (7).

The activation entropy value of thermal inactivation $(0.590$ $\mathrm{kJ} / \mathrm{mol} . \mathrm{K}$ ) is also very low which reflects that this inactivation phenomenon implies a little randomness increase during the

Table 4. Thermodynamic parameters estimated by Arrhenius approach for batch formation of L-DOPA from glucose by Aspergillus oryzae and its mutant derivative.

\begin{tabular}{|c|c|c|c|}
\hline \multicolumn{2}{|l|}{ Parameter/strain } & \multirow{2}{*}{$\begin{array}{c}\begin{array}{c}\mathrm{L}-\mathrm{DOPA} \\
\text { formation }\end{array} \\
42^{\mathrm{a}}\end{array}$} & \multirow{2}{*}{$\begin{array}{c}\begin{array}{c}\text { Thermal } \\
\text { inactivation }\end{array} \\
97^{\mathrm{b}}\end{array}$} \\
\hline Activation enthalpy & Parental strain & & \\
\hline$(\mathrm{kJ} / \mathrm{mol})$ & Mutant strain & $40^{\mathrm{a}}$ & $116^{\mathrm{a}}$ \\
\hline \multirow{3}{*}{$\begin{array}{l}\text { Activation entropy } \\
(\mathrm{kJ} / \mathrm{mol} . \mathrm{K})\end{array}$} & & & \\
\hline & Parental strain & $(-) 0.079^{a}$ & $0.534^{\mathrm{b}}$ \\
\hline & Mutant strain & $(-) 0.076^{\mathrm{h}}$ & $0.590^{\mathrm{a}}$ \\
\hline
\end{tabular}

Values followed by different letters differ significantly at $\mathrm{p} \leq 0.05$. Enthalpy values $\left({ }_{\Delta} \mathrm{H}\right)$ were calculated from slopes of straight lines in Fig. 4 (Slope = $\left.{ }_{-} \mathrm{H} / \mathrm{RT}\right)$ and entropies $\left({ }_{\Delta} \mathrm{S}\right)$ were calculated from the intercepts on Y-axis (Intercept $\left.=\mathrm{Ln}\left(\mathrm{K}_{\mathrm{B}} / \mathrm{h}\right)+{ }_{\Delta} \mathrm{S} / \mathrm{R}\right)$ where $\mathrm{K}_{\mathrm{B}}$ is Boltzmann, $\mathrm{s}$ constant, $\mathrm{h}$ is Planck's constant and $\mathrm{R}$ is gas constant.
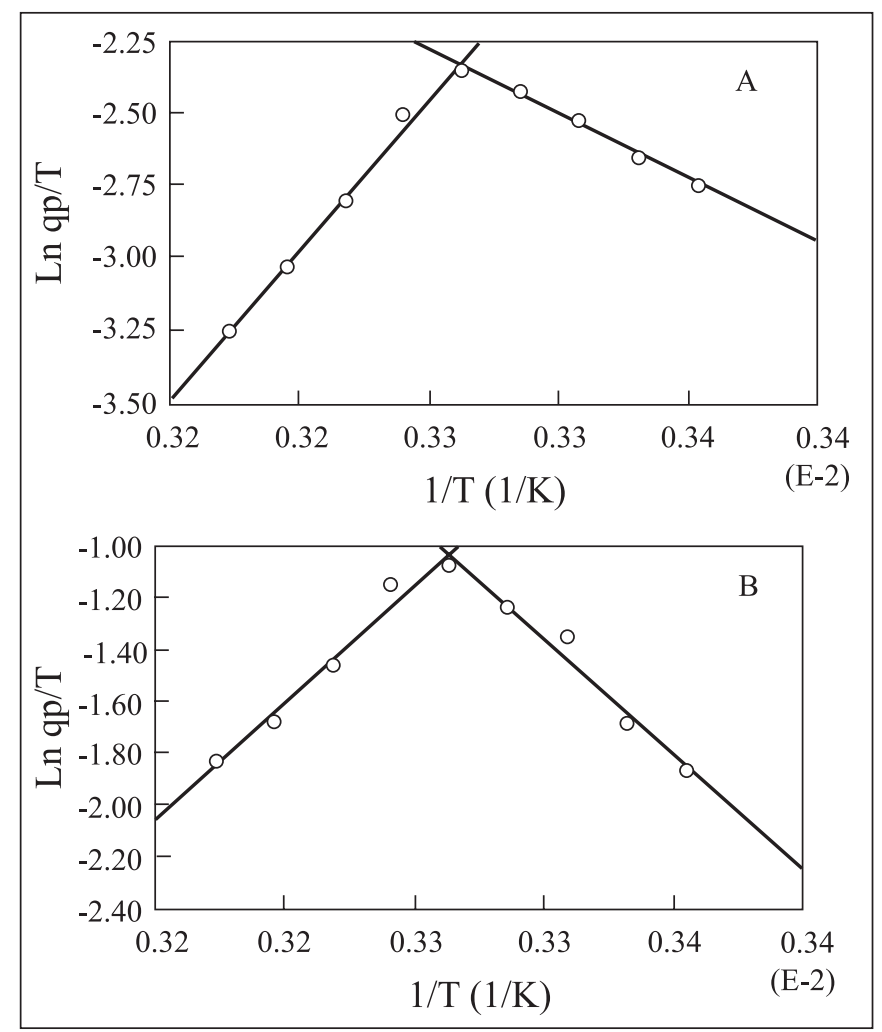

Figure 4. Application of Arrhenius model to calculate enthalpy and entropy of L-DOPA production by tyrosinase produced by Aspergillus oryzae (A) and its mutant derivative (B) by application of equation 2 given in text.

activated state formation, practically this value is lower than those estimated for some other enzymatic systems $(0.89 \mathrm{~kJ} /$ mol.K) (2). This suggests a sort of protection exerted by mutated cell system against thermal inactivation. In the parental cells, these values were higher and suggested that mutant cells were thermodynamically more resistant to thermal inactivation.

To calculate specific productivity $\left(\mathrm{q}_{\mathrm{p}}\right)$ of L-DOPA at different temperature of reaction mixture, repeat experiments were performed at different temperature of reaction in time course study (see Materials and Methods). Above relationship was again applied to data achieved in these experiments and results have been presented in Fig. 5. The values of activation enthalpy and entropy were $40 \mathrm{~kJ} / \mathrm{mol} . \mathrm{K}$ and $0.014 \mathrm{~kJ} / \mathrm{mol} . \mathrm{K}$, respectively for L-DOPA production by mutant culture while their values of activation enthalpy for denaturation $\left({ }_{\triangle} \mathrm{H}_{\mathrm{D}} *\right)$ and activation entropy for denaturation of L-DOPA $\left({ }_{\triangle} \mathrm{S}_{\mathrm{D}} *\right)$ were $57 \mathrm{~kJ} / \mathrm{mol}$ and 0.284 $\mathrm{kJ} / \mathrm{mol}$.K, respectively. Corresponding values for parental cultures were $54 \mathrm{~kJ} / \mathrm{mol}$ and $0.045 \mathrm{~kJ} / \mathrm{mol}$.K for activation enthalpy and entropy, respectively for L-DOPA production 

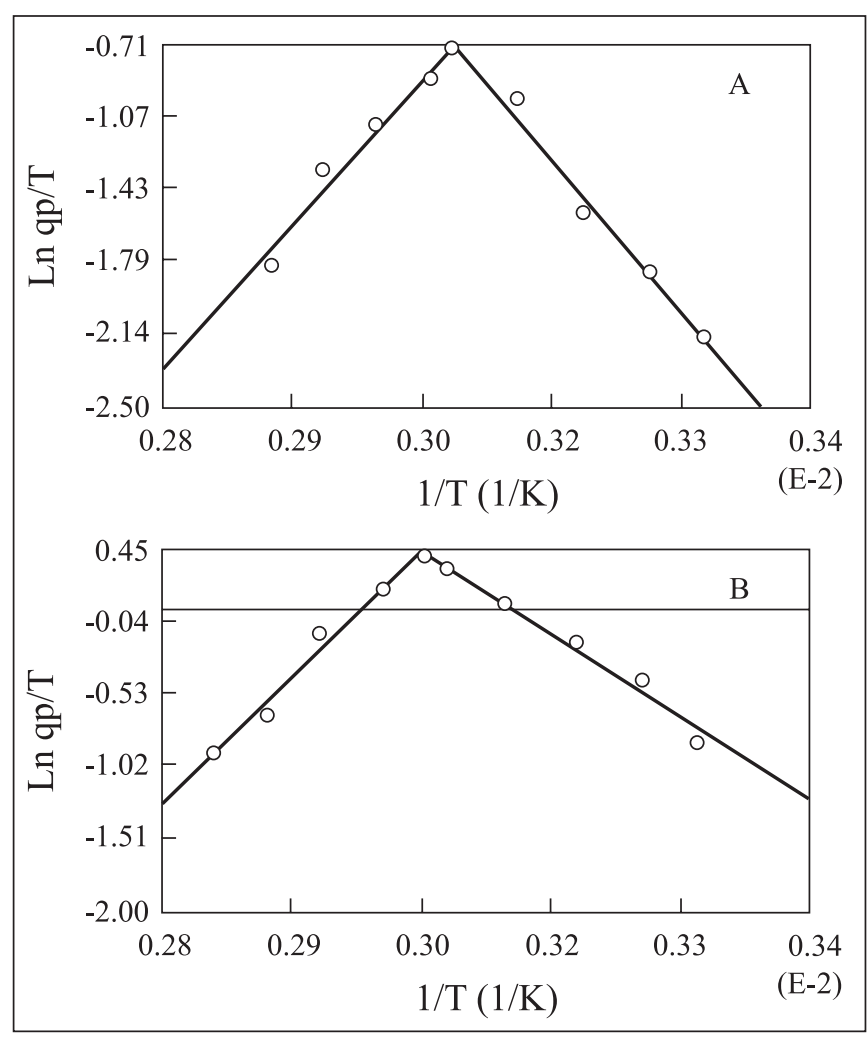

Figure 5. Application of Arrhenius model to calculate enthalpy and entropy of L-DOPA production by tyrosinase produced by Aspergillus oryzae (A) and its mutant derivative (B) in reaction mixture performed at different temperature $\left(35-75^{\circ} \mathrm{C}\right)$ by application of equation 2 given in text.

while they were $49 \mathrm{~kJ} / \mathrm{mol}$ and $0.270 \mathrm{~kJ} / \mathrm{mol} . \mathrm{K}$ for thermal denaturation, respectively. These experiments also indicated that the mutant cells exerted more resistance to thermal deactivation than the parental culture.

In these studies, $\mathrm{q}_{\mathrm{p}}$ values have been used to calculate activation enthalpy and entropy for product formation and its deactivation after Aiba et al. (1) while other workers used $\mathrm{Q}_{\mathrm{p}}$ values to calculate these parameters $(2,3,7)$. It was found that the values calculated by this model ere comparable with those obtained with latter method.

\section{CONCLUSION}

A mutant of Aspergillus oryzae has been obtained which has the ability to hyper produce L-DOPA from L-tyrosine. The volumetric and specific productivities of L-DOPA were higher than the deduced values reported by other workers. The tyrosinase produced by this mutant was partially feedback inhibition-resistant by L-DOPA $(7.0 \mathrm{mM})$ as compared with enzyme preparation reported by Pialis and Saville (19) who reported 50\% reduction in the production of L-DOPA due to competitive inhibition caused by L-DOPA $(1.0 \mathrm{mM})$. The enzyme system harbored by the mutant strain was thermodynamically more thermostable than that possessed by its parental cultures and exerted remarkable protection against thermal denaturation. We intend to improve the production of tyrosinase by isolating feedback inhibition-resistant mutant derivative along with optimizing the nitrogen and carbon sources to support production of elevated profiles of L-DOPA, a landmark in neurosciences as it has the ability to control Parkinson's disease, which was considered to be disabling ailment.

\section{ACKNOWLEDGEMENTS}

These studies were supported in part by Pakistan Science Foundation. Vice Chancellor, Government College University Lahore and Chairman, Department of Botany are appreciated for providing the facilities to complete this work.

\section{RESUMO}

\section{Mutação de Aspergillus orizae para produção melhorada de 3,4-dihidroxi fenil-L-alanina (L-DOPA) a partir de L-tirosina}

A produção de L-DOPA a partir de tirosina pela cepa mutante de Aspergillus orizae UV-7 foi melhorada através de mutação química. Diferentes cepas foram testadas quanto a produção de L-DOPA por fermentação submersa, observando-se que a cepa denominada SI-12 foi a melhor produtora $(300 \mathrm{mg}$ de L-DOPA por $\mathrm{g}$ de células). A produção de L-DOPA pela cepa mutante a partir de diferentes fontes de carbono foi testada em diferentes fontes de nitrogênio, $\mathrm{pH}$ inicial e temperatura. Em pH ótimo $(5,0)$ e temperatura ótima $\left(30^{\circ} \mathrm{C}\right)$, todos os açúcares foram utilizados para formação de biomassa, com um rendimento de L-DOPA de $150 \mathrm{mg} . \mathrm{g}^{-1}$, e produtividade volumétrica máxima e especifica de $125 \mathrm{mg} .1 . \mathrm{h}^{-1} \mathrm{e} 150 \mathrm{mg} \cdot \mathrm{g}^{-1} \cdot \mathrm{h}^{-1}$, respectivamente. A velocidade de formação do produto aumentou 3 vezes, sendo esse aumento o maior já relatado na literatura. Para explicar o mecanismo cinético da formação de L-DOPA e a inativação térmica da tirosinase, os parâmetros termodinâmicos foram determinados aplicando-se o modelo de Arrhenius: no caso da cepa mutante, a entalpia de ativação e entropia foram $40 \mathrm{kj} / \mathrm{mole}$ e, $076 \mathrm{kj} / \mathrm{mol}$.K para produção de L-DOPA e $116 \mathrm{kj} / \mathrm{mol}$ and $0,590 \mathrm{kj} / \mathrm{mol}$.K para inativação térmica, respectivamente. Os valores para formação do produto foram mais baixos e os para desativação do produto foram mais elevados que os valores correspondentes à cultura parental, indicando que a cepa mutante foi termodinamicamente mais resistente à denaturação térmica.

Palavras-chave: Aspergillus orizae, L-DOPA, parâmetros termodinâmicos 


\section{REFERENCES}

1. Aiba, S.; Humphrey, A.E.; Millis, N.F. Biochemical Engineering. $2^{\text {nd }}$ Edition, New York; Academic Press, 1973, pp. 92-127.

2. Al-Asheh, S.; Duvniak, Z. Characteristics of phytase produced by Aspergillus carbonarius NRC 401121 in canola meal. Acta Biotechnol., 14, 223-237, 1994.

3. Arni, S.; Molinari, F.; Del Borghi, M.; Converti, A. Improvement of alcohol fermentation of a corn starch hydrolysate by viscosityraising additives. Starke/Starch, 51, 218-224, 1999.

4. Arnow, L.E. Colorimetric determination of the components of L-3, 4-dihydroxyphenylalanine-tyrosine mixture. J. Biochem., 118, 531534, 1937.

5. Carvalho, G.M.; Alves, T.L.; Freire, D.M. L-DOPA production by immobilized tyrosinase. J. Appl. Biochem. Biotechnol., 84-86, 791$800,2000$.

6. Converti, A.; Borghi, M. Simultaneous effects of immobilization and substrate protection on the thermodynamics of glucose isomerase activity and inactivation. Enzyme Microb. Technol., 21, 511-517, 1997.

7. Converti, A.; Dominguez, J.M. Influence of temperature and $\mathrm{pH}$ on xylitol production from xylose by Debarryomyces hansenii. Biotechnol. Bioeng., 75, 39-45, 2001.

8. Das, A.; Nandi, P. Production and characterization of inducedmutation in Aspergillus sp. J. Ferment. Technol., 13, 633-635, 1977.

9. Evans, W.C.; Raper, H.S. A comparative study of the production of L-3, 4 dihydroxyphenylalanine from tyrosine by tyrosinase from various sources. Biochem. J., 31, 2155-2166, 1973.

10. Haneda, K.S.; Watanabe, J.; and Takeda, P. Production of L-3, 4dihydroxyphenylalanine from L-tyrosine by microorganisms. $J$. Ferment. Technol., 51, 398-406, 1973.

11. Haneda, K.; Takeda, I. Activation of enzyme of Aspergillus oryzae catalyzing the conversion of L-tyrosine to L-3, 4dihydroxyphenylalanine. J. Ferment. Technol., 52, 106-113, 1974.

12. Haq, I.; Ali. S. Microbiological transformation of L-tyrosine to 3, 4dihydroxyphenyl L-alanine (L-DOPA) by a mutant strain of Aspergillus oryzae. Curr. Microbiol., 45, 88-93, 2002.
13. Kim, L.T.; Heo, B.J.; Kim, H.P. L-DOPA auto-oxidantion and inhibitory activities of tyrosinase. J. Cosmet Sci., 19, 291-298, 1997.

14. Lawford, H.G.; Fousseau, J.D. Mannose fermentation by ethanologenic recobinants of Escherichia coli. Biotechnol. Lett., 15, 615-620, 1993.

15. Lee, S.G.; RO, H.S.; Hong, S.P.; Kim, E.H.; Sung, M.H. Production of L-DOPA from thermostable tyrosine phenyl-lyase of a thermophilic Symbiobacterium sp. over expressed in Escherichia coli. J. Microb. Biotechnol., 6, 98-102, 1996.

16. Lee, S.G.; Hong, S.P.; Sung, M.H. Development of an enzymatic system for the production of dopamine from catechol, pyruvate, and ammonia. Enzyme Microb. Technol., 25, 268-302, 1999.

17. Loganathan, P. Production of L-DOPA from acellular slime mould Stemonotis herbatica. Bioproc. Eng., 18, 307-308, 1998.

18. Olsen, W. Characterization of enzymes using catecholamines. Sugar J., 83, 102-105, 1981

19. Pialis, P.; Saville, B.A. Production of L-DOPA from tyrosinase immobilization on nylon6-6: Enzyme stability an scale up. Enzyme Microb. Technol., 22, 261-268, 1998.

20. Rajoka, M.I.; Bashir, A.; Malik, K.A. Mutagenesis of Cellulumonas biazotea for enhanced production of xylananse. Biores. Technol., 62, 99-108, 1997.

21. Rajoka, M.I.; Bashir, A.; Hussain, M-R.A.; malik, K.A. Mutagenesis of Cellulomonas biazotea for improved production of cellulase. Folia. Microbiologia, 43, 15-22, 1998.

22. Raju, B.G.S.; Rao, G.H.; Ayyana, C. Bioconversion of L-tyrosine to L-DOPA using Aspergillus oryzae. Visakhapatnam, India, 1993, pp. 106-110.

23. Rasazza, J.; Foss. P.; Lemberge, F.; Sih, C.J. The microbial synthesis of L-DOPA. J. Biol. Chem., 63, 544-547, 1974.

24. Roels, J.A. Energetics and kinetics in biotechnology. Amsterdam: Elsevier Biomedical, In Press.

25. Sih, C.J.; Foss, P.; Rosazza, J.; Lembagar, M. Microbial synthesis of L-3,4-dihydroxy phenylalanine. J. Am. Chem. Soc., 91, 6204-6207, 1969. 